\section{Student Perceptions of Authoring a Publication Stemming from a Course- Based Undergraduate Research Experience (CURE)}

\author{
Ashley N. Turner, ${ }^{\dagger}$ Anil K. Challa, ${ }^{\dagger}$ and Katelyn M. Cooper ${ }^{\S *}$ \\ 'Department of Biology, School of Science, Jacksonville State University, Jacksonville, AL 36265; \\ ‡Department of Biology, College of Arts and Sciences, University of Alabama at Birmingham, \\ Birmingham, AL 35294; \$Research for Inclusive STEM Education Center, School of Life Sciences, \\ Arizona State University, Tempe, AZ 85281
}

\begin{abstract}
Course-based undergraduate research experiences (CUREs) engage students in authentic research experiences in a course format and can sometimes result in the publication of that research. However, little is known about student-author perceptions of CURE publications. In this study, we examined how students perceive they benefit from authoring a CURE publication and what they believe is required for authorship of a manuscript in a peer-reviewed journal. All 16 students who were enrolled in a molecular genetics CURE during their first year of college participated in semistructured interviews during their fourth year. At the time of the interviews, students had been authors of a CURE publication for a year and a half. Students reported that they benefited personally and professionally from the publication. Students had varying perceptions of what is required for authorship, but every student thought that writing the manuscript was needed, and only two mentioned needing to approve the final draft. Additionally, we identified incomplete conceptions that students had about CURE publications. This work establishes student-perceived benefits from CURE publications and highlights the need for authorship requirements to be explicitly addressed in CUREs.
\end{abstract}

\section{INTRODUCTION}

Course-based undergraduate research experiences (CUREs) provide students with the opportunity to engage in research in the context of a course and can result in many of the same benefits as traditional undergraduate research experiences in faculty member labs (Auchincloss et al., 2014; Brownell and Kloser, 2015; Corwin et al., 2015; Linn et al., 2015; National Academies of Sciences and Medicine, 2017). For example, CUREs have been shown to enhance students' critical-thinking skills (Jordan et al., 2014; Brownell et al., 2015), improve students' science identity (Bhatt and Challa, 2017; Cooper et al., 2020), bolster students' abilities to navigate scientific obstacles (Gin et al., 2018), and increase student persistence in undergraduate science (Rodenbusch et al., 2016). In addition, CUREs often have the potential to lead to student-authored, peer-reviewed scientific publications, which could potentially benefit both CURE instructors as well as CURE students (Shortlidge et al., 2015, 2017).

CUREs likely increase the number of students who will publish a peer-reviewed journal article stemming from the research they conducted as an undergraduate (Bangera and Brownell, 2014). While only a subset of students have the opportunity to engage in a traditional undergraduate research experience due to the limited number of spots at most institutions (Wood, 2003; President's Council of Advisors on Science and Technology, 2012), even fewer undergraduates have the opportunity to author publications. In a survey of 1,272 life sciences undergraduate researchers
Stephanie Gardner, Monitoring Editor Submitted Mar 1, 2021; Revised Jul 1, 2021; Accepted Jul 8, 2021

CBE Life Sci Educ September 1, 2021 20:ar46 DOI:10.1187/cbe.21-02-0051

*Address correspondence to: Katelyn M. Cooper (Katelyn.cooper(a)asu.edu).

(c) 2021 A. N. Turner et al. CBE-Life Sciences

Education $\odot 2021$ The American Society for Cell Biology. This article is distributed by The American Society for Cell Biology under license from the author(s). It is available to the public under an Attribution-Noncommercial-Share Alike 3.0 Unported Creative Commons License (http://creativecommons.org/licenses/ by-nc-sa/3.0).

"ASCB $®$ " and "The American Society for Cell Biology $\AA^{\circ}$ are registered trademarks of The American Society for Cell Biology. 
across 87 institutions, only $8.8 \%$ reported having been an author on a peer-reviewed publication (Gin et al., unpublished data). In fact, undergraduates do not list authoring publications among what they expect to gain from undergraduate research (Mabrouk and Peters, 2000). It is not surprising that so few undergraduates publish. Publications authored by undergraduates have been associated with students working for more than one year on average with a faculty mentor (Morales et al., 2017), and many students do not begin undergraduate research until later in their academic careers. So, depending on the length and stage of the project, there may not be time for them to contribute enough to a project to become an author. However, other factors such as the scientific discipline, the advisor, and the research project likely also contribute to whether a project results in publication (Holliday et al., 2014; Schmieder et al., 2021).

CUREs provide a potentially less competitive and time-consuming avenue to publication for undergraduates. In addition, given the constraints of time and scope, CUREs are likely to be more structured than individual mentored-research experiences. Students often enroll in a CURE just as they would in any regular science course, that is, they do not have to compete for a limited number of spots as they often would for a traditional undergraduate research experience in a faculty lab (Bangera and Brownell, 2014). Additionally, CURE instructors are often able to troubleshoot experiments before the course and outline specific tasks that need to be accomplished to complete the research project (Gin et al., 2018; Cooper et al., 2019a, 2020); these factors likely expedite the time between an undergraduate getting involved in a CURE and producing data suitable for publication. While it is unknown exactly what percentage of CUREs result in scientific publications, an interview study of 33 CURE developers found that $61 \%$ of participants reported that a benefit of CUREs is that they can lead to publications, and $26 \%$ reported publishing a scientific research article that resulted from their CURE (Shortlidge et al., 2015), though it was not indicated whether CURE students were coauthors on these publications. Publications stemming from CUREs with CURE students as authors (referred to as "CURE publications" henceforth) have been published across biology disciplines, including genetics (Call et al., 2007; Olson et al., 2019), genomics (Leung et al., 2015), nanochemistry (Pozun et al., 2011), biotechnology (Umali et al., 2011), molecular biology (Hall et al., 2010), plant biology (Lellis et al., 2010), cell biology (Malone et al., 2008), and biology education (Cooper et al., 2018, 2019b; Nadile et al., 2021).

Whether students in CUREs are able to contribute enough to warrant being an author on a publication is debatable. The length of a CURE is much shorter than most traditional undergraduate research experiences, so some researchers are skeptical that students have put enough "time" into the publication. There are varying levels of student intellectual engagement in CUREs; some CUREs have students follow prescribed protocols to obtain novel, potentially publishable data, but students play little role in the design (Jordan et al., 2014; Brownell et al., 2015; Cooper et al., 2019a), while at the other extreme, students in some CUREs come up with the research question and methods (Kloser et al., 2013). Students in a CURE often have the common experience of working on a shared research project (Nadile et al., 2021) or parallel, related research projects
(Shaffer et al., 2010; Cooper et al., 2020), but their individual contributions can vary drastically.

Another aspect that makes authorship debatable is that authorship guidelines vary by journal and publisher. A survey of 234 biomedical journals found that $41 \%$ provided no guidance about authorship, $14 \%$ proposed their own unique criteria, $14 \%$ only stated that authors should approve the manuscript, and $29 \%$ based their instructions on the criteria of the International Committee of Medical Journal Editors (ICMJE; Wager, 2007). The ICMJE declares that, in order for individuals to qualify for authorship, they must 1) substantially contribute to the conception and design of the study, or acquisition of data, or interpretation of data; and 2) draft the study manuscript or critically revise it for important intellectual content; and 3) give final approval of the version to be published; and 4) agree to be accountable for all aspects of the work in ensuring that questions related to the accuracy or integrity of any part of the work are appropriately investigated and resolved (ICMJE, 2019). ICMJE further recommends that all individuals who meet the first criterion should be invited to participate in the review, drafting, and final approval of the manuscript.

A publication with over 900 undergraduate authors that stemmed from a well-established CURE, the Genomics Education Partnership (Leung et al., 2015), raised questions about whether the CURE students had made substantial enough contributions to be credited as authors (Woolston, 2015). In response to these questions, one of the CURE developers argued that it is sufficient for student authors in a CURE to read, critique, and approve the manuscript in addition to making a significant intellectual contribution during the CURE itself (Woolston, 2015). While most CURE papers have far fewer authors, conversations about what students need to contribute in order to be considered for authorship on a CURE publication have been lacking.

The National Institutes of Health (NIH), the National Science Foundation (NSF), and the National Academies of Science and Medicine have called for training individuals to understand responsible authorship and publication ethics (National Academies of Sciences, Engineering, and Medicine, 2017; NIH, 2019; NSF, 2020). However, it is unlikely that information about ethical authorship is being regularly integrated into the undergraduate curriculum (Abbott et al., 2020). One study of 68 undergraduates who were entering research programs in science and engineering found that more than one-third of students were unable to define the term "authorship." Even after participating in a workshop on responsible conduct in research (RCR), about a quarter of students still struggled to define that term correctly (Mabrouk, 2016). Additionally, an in-depth interview study of 18 undergraduate researchers found that authorship was not routinely discussed in their research groups (Abbott et al., 2020). Specifically in the context of CUREs, the Ethics Network for Course-based Opportunities in Undergraduate Research has recently called for integrating curricula related to the principles of ethics/RCR into CUREs and highlighted authorship and authors' responsibilities as key topics that should be addressed within RCR curriculum (Olimpo et al., 2017; Diaz-Martinez et al., 2019).

Why should CURE instructors include students as authors on publications? In addition to the ethical arguments for including students who have contributed to a research project, authorship 


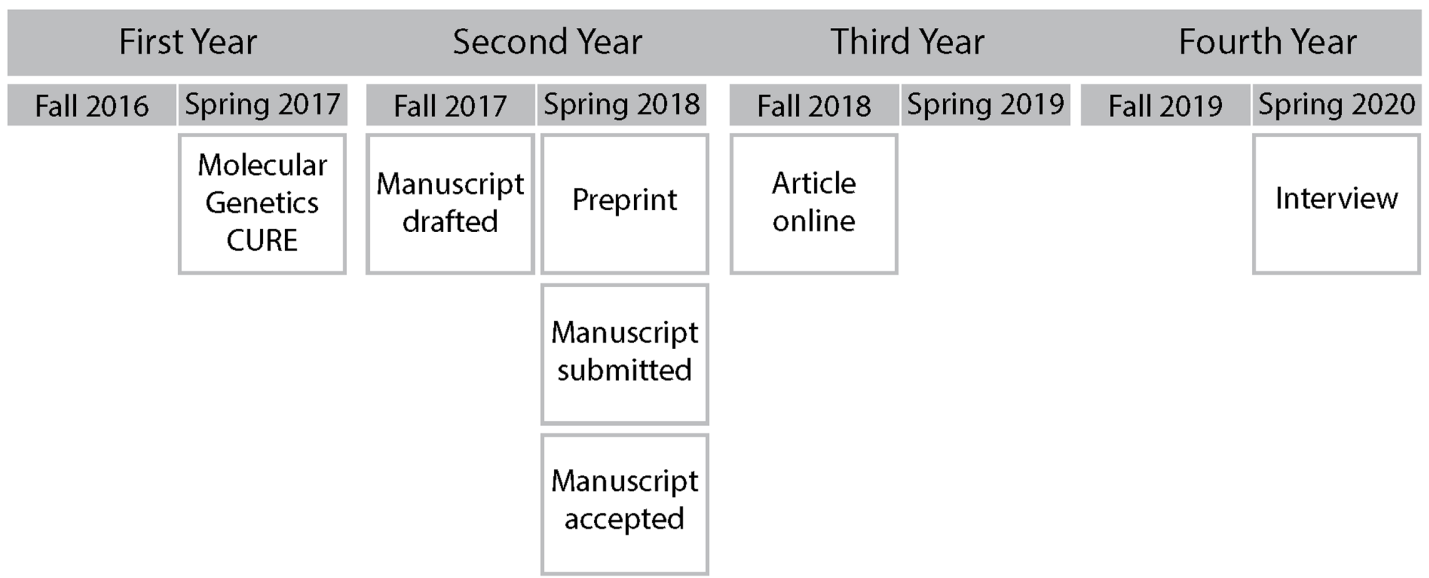

FIGURE 1. Timeline of CURE, CURE publication, and student interviews.

likely provides many benefits to students. Understanding how students benefit from CUREs is a critical component of second-generation CURE research, which aims to delineate what elements of CUREs lead to specific benefits (Corwin et al., 2015; Linn et al., 2015). Authoring a CURE publication may prepare students for scientific careers (Hunter et al., 2007), and students likely leverage CURE publications to further their careers, given the importance that graduate and professional schools place on publications (Cooper et al., 2019c). Additionally, CURE publications may be a source of external validation for students, which has been suggested to further solidify their role in the scientific community (Lave and Wenger, 1991; Corwin et al., 2015). Yet, despite these hypotheses, there are no documented benefits of students authoring CURE publications.

Overall, there is little known about the experiences of students who author CURE publications. Specifically, it is unknown to what extent students perceive that they benefit from CURE publications and how they view authorship, especially in the context of a CURE. To begin to address these gaps in the literature, we conducted an in-depth interview study of students enrolled in a CURE that resulted in a CURE publication (Turner et al., 2018a). We interviewed every student enrolled in the CURE just before the students graduated college, a year and a half after their work had been published. We sought to further understand:

1. How, if at all, do students perceive that they have benefited from authoring a CURE publication?

2. What are student perceptions of what constitutes authorship of peer-reviewed scientific publications?

\section{METHODS}

This study was done with an approved Institutional Review Board protocol no. IRB-300005217 from the University of Alabama at Birmingham.

Description and Timing of the CURE and CURE Publication Sixteen students were enrolled in a molecular genetics CURE at a research-intensive (R01) public institution in the United States during their second semester of college in Spring 2017. The CURE took place over a single semester. The data produced in the CURE were used to draft a manuscript during the Fall of 2017, with all students as coauthors. One instructor of the CURE was listed as the first author followed by all students in the class listed alphabetically by last name. Two students who served as peer mentors were listed next, and the primary instructor of the CURE was the last author. The manuscript was submitted to bioRxiv as a preprint article in March 2018 (Turner et al., 2018b), submitted for peer review in April 2018, accepted in June 2018, and published online in December 2018 (Turner et al., 2018a). Students were interviewed about the publication just before they graduated during Spring 2020. See Figure 1 for a timeline of the CURE, CURE publication, and student interviews.

The focus of the CURE was to introduce experimental research to students using the CRISPR-Cas9 genome engineering system. Using a combination of bioinformatics and "wet lab" tools, students designed, synthesized and analyzed CRISPR reagents that effectively targeted specific sites within a zebrafish gene of interest. Students used the zebrafish as a model system to generate domain-specific mutations and understand the structure-function of the ndr2 gene. A general overview and curriculum of an earlier version of this CURE has been published (Bhatt and Challa, 2017). The specific activities that students engaged in during the CURE are outlined in Figure 2. Each student worked on the design, synthesis, and analysis of the guide RNA they identified within the target gene; every student had to submit individual products resulting from laboratory experiments. However, students worked collaboratively in teams (four students per team) and the larger class group (16 students) to perform and troubleshoot experiments and to discuss their findings. Beyond analyzing microinjected zebrafish embryos for phenotypes, students primarily collaborated in their teams and the larger class group. At the end of the semester, each team presented a poster at a university-wide research exposition. A detailed chart describing each student's individual contribution to the research project and manuscript is included in the Supplemental Material.

All students enrolled in the CURE were part of a university honors program focused on science and technology. Students had applied to the honors program before coming to college, and the program selected high-performing students by considering a number of factors, including high school grade point 


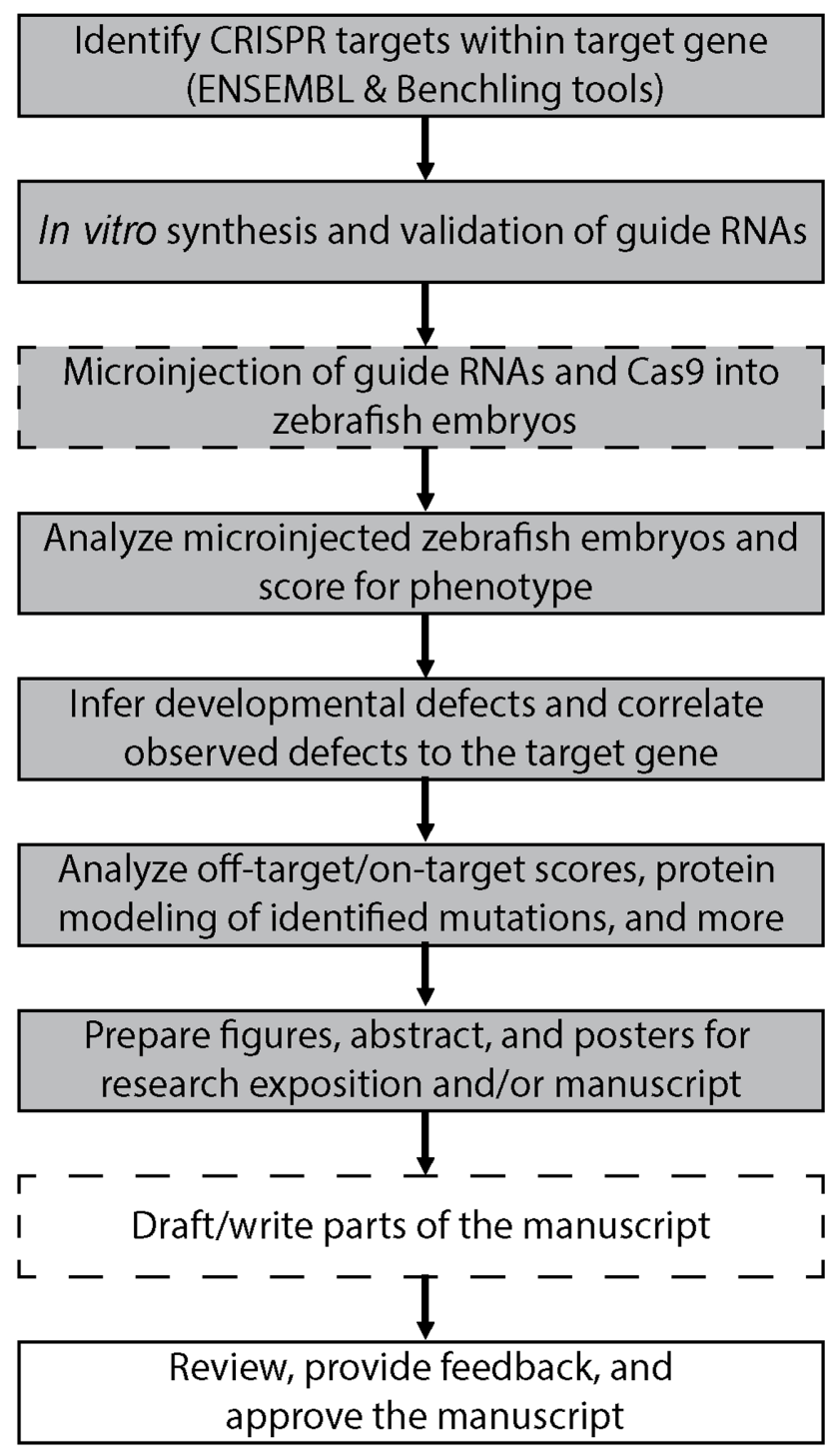

FIGURE 2. Specific activities that students engaged in during and after the CURE. Boxes with a solid outline signify a required activity and boxes with a dashed outline signify an activity that students were invited to volunteer to participate in, but that was not required as part of the course or to be an author on the CURE manuscript. Shaded boxes indicate activities that occurred during the semester of the CURE and white boxes indicate activities that occurred after the CURE had ended.

average (GPA) and Scholastic Aptitude Test/ACT scores. In the first semester of the honors program, students engage in a course that introduces them to primary research articles from scientific journals and enables them to read, analyze, and present the findings from those published articles. In the second semester, students enroll in a course in which they engage with methods and skills involved in laboratory research; the CURE was one option that students in the honors program could choose during Spring 2017. Before the students' second semester, they complete a series of online training modules for Occupational Health and Safety on topics ranging from basic biosafety to personal protective equipment; however, students did not complete any RCR training as part of the honors program.
The CURE was taught by two instructors (the course director and a graduate teaching assistant) who told students that the research that they were conducting in the class could potentially result in a publication due to the novel and broadly relevant nature of the research question. As the CURE progressed and students' work yielded publishable results, the instructors explicitly told the students that the results would be drafted into a manuscript and submitted for publication and that they could be authors on the manuscript. The instructors explained that the manuscript would be written after the course had ended, primarily over the following summer and fall, and that students would be invited to participate in the writing of the manuscript. The CURE instructors did not discuss specific authorship requirements, such as the ICMJE standards, in the CURE. However, after the course was complete and the manuscript was being drafted, they communicated with students that, as authors, they should be able to explain the project and their specific contributions to anyone. They were also told they would need to read the manuscript, provide feedback and edits, and approve the final manuscript before submission.

In Summer 2017, the CURE instructors took the lead on drafting the manuscript and invited all students to collaborate on it using a shared Google Doc. On the first draft of the manuscript, two of the 16 students contributed short write-ups in the introduction and summary of the study that were approximately two paragraphs each. Throughout this time, the two students were still in the honors program and regularly communicated with the rest of the 14 CURE students, who were aware of their written contributions to the manuscript. The instructors of the course revised the writing so that the manuscript would have one voice, but maintained the ideas of these two students. When the manuscript was at a final stage, it was circulated among all students in the course, and the instructors explicitly requested student feedback in the form of tracked changes and comments on a Word document. Students provided varied levels of feedback on the manuscript. After relevant student comments were incorporated, a final draft of the manuscript was sent to all students. Students were explicitly told via email that they needed to approve the final manuscript and take responsibility for the work presented in order to be considered an author; this process occurred twice, once before the manuscript was submitted as a preprint and once before it was submitted to the peer-reviewed journal. Reviewers for the journal requested minor revisions before publication. The revisions were completed by the instructors of the course, and the revised manuscript was sent to and approved by all students. The instructors of the course felt confident in their decision to include students as authors on the manuscript, given their contributions: 1) students made a substantial contribution to the design of experiments and the acquisition, analysis, and interpretation of the data, and presented their work to faculty and students at a university-wide student research exposition; 2) students revised the manuscript; 3) students approved the final version of the manuscript to be published; and 4) students agreed that they were accountable for their contribution to the project as well as the final manuscript as a whole. These contributions align with the ICMJE standards; however, the instructors agreed that students' feedback on the final version of the manuscript varied in terms of the content provided. 


\section{Student Interviews}

In Spring 2020, when students were completing their fourth year at the university, the semester most students were expecting to graduate, we reached out to all students who were initially involved in the CURE and invited them to participate in a semistructured interview about their experience in the CURE. All 16 students originally enrolled in the CURE consented to the study and participated in an interview. We developed an interview script to explore our research questions. Specifically, we were interested in how, if at all, students perceived they had benefited from the CURE publication, to what extent students believed they personally deserved authorship on the CURE publication, and what students perceived constitutes authorship on peer-reviewed publications broadly. To pilot our interview script and ensure cognitive validity, or that each interview question was clearly addressing what we perceived it to be asking, we conducted think-aloud interviews with two students who had authored publications as undergraduate researchers. Questions were revised after each think-aloud interview until we felt that no question was unclear or misinterpreted by the students (Trenor et al., 2011). A copy of the interview script can be found in the Supplemental Material. All interviews were conducted by one researcher (A.N.T.). The interviews were approximately an hour long, and students were incentivized with a small monetary gift. All interviews were de-identified and transcribed before analysis.

\section{Interview Analysis}

Two members of the research team (A.N.T. and K.M.C.) individually reviewed a different set of eight interviews and took detailed analytic notes to explore each idea that a participant expressed (Charmaz, 2006) and to identify recurring ideas throughout the interviews (Birks and Mills, 2015). We then compared our notes and created a rubric describing each recurring theme (Saldaña, 2015). Together, we reviewed a random set of eight interviews using the rubric to ensure that the rubric captured all themes and that no new themes emerged. Using constant comparison methods, we assigned quotes to each theme and constantly compared the quotes to ensure that each quote fit within the description of the theme (Glesne and Peshkin, 1992). Data saturation was reached within the first eight interviews (Guest et al., 2006). Together, we revised the set of themes and defined a final set of codes; we created a final codebook, which can be found in the Supplemental Material. Once the final codebook was established, we individually coded four randomly selected interviews (25\% of all interviews) using the coding rubric. We compared our codes, and our Cohen's $\kappa$ interrater score was at an acceptable level ( $\kappa$ $=0.81$; Landis and Koch, 1977). One member of the research team (A.N.T.) coded the remaining 12 interviews.

When examining the ways in which students perceived the benefits from the CURE publication, we report out themes that were reported by more than a quarter of CURE students. In addition to examining students' explicit responses to the question asking how, if at all, they had benefited from the CURE publication, we examined the interview as a whole for any other benefits that students mentioned. We were most interested in benefits that seemed to be relevant for multiple students; however, because these questions were open-ended, we are likely underreporting the percentage of students who benefited in a particular way.
When investigating the conditions that students perceived as requirements for being considered to be an author on a peer-reviewed publication, we used deductive coding (Creswell, 1994) to identify the presence of ICMJE authorship criteria (ICMJE, 2019). We chose to use the ICMJE to guide the analysis, as it is the most commonly used set of guidelines for authorship in biomedical journals (Wager, 2007). Additionally, we also used inductive coding (Thomas, 2003) to identify additional criteria that students considered. Criteria that a student mentioned as well as the percentage of students who mentioned each ICMJE criterion are reported. When analyzing student definitions of the term "intellectual contribution," we report the most common student responses. Throughout the interviews, we also noted incomplete conceptions that students held about authorship. We report out the most common incomplete conceptions shared by students.

Inferences made about the importance of these themes cannot be drawn from the percentage of students who reported a particular theme (Maxwell, 2010). Further, with the limited number of interviewees, it is not possible to examine whether there were trends or correlations related to student demographics. Quotes were subtly edited for clarity by inserting clarification brackets and using ellipses to indicate excluded text.

\section{CURE Participants}

Information about student demographics and their additional experiences with undergraduate research were collected on a survey provided to students after the interview (a copy of the survey questions can be found in the Supplemental Material). Student demographics and additional research experiences and authored publications are summarized in Table 1.

\section{RESULTS \\ Finding 1: Students Highlighted 10 Ways in which They Perceived They Benefited from Authoring a CURE Publication}

When we asked students explicitly how, if at all, they benefited from authoring the CURE publication, they highlighted an array of ways in which they perceived that they benefited. There were 10 distinct benefits that were each mentioned by at least five students (31.3\%). Students highlighted each benefit with reference to the CURE publication specifically, as opposed to engaging in the CURE broadly. The student-perceived benefits can be organized into three overarching groups: 1) positively influenced students personally, 2) positively influenced students professionally, and 3) changed the way students think about science and research (Table 2).

Personal Perceived Benefits of Authoring a CURE Publication. All of the students we interviewed highlighted that they shared the publication with people in their personal lives, which yielded positive exchanges between the student and the individual(s) they shared it with. Students described sharing it with their friends and acquaintances (often on social media platforms), with other researchers who were friends, with past teachers, and with family and significant others. Some students described sharing it in order to prove to others that they had been productive during their first year in college, while most students shared this accomplishment with the intent to celebrate the good news with others in their lives. Some students 
TABLE 1. Participant demographics

\begin{tabular}{lc}
\hline & $\begin{array}{c}N=16 \\
\%(n)\end{array}$ \\
\hline Gender & \\
Woman & $43.8(7)$ \\
Man & $50(8)$ \\
Genderfluid & $6.2(1)$ \\
Race/ethnicity & \\
Black or African American & $6.2(1)$ \\
Hispanic, Latinx, or Spanish origin & $6.2(1)$ \\
White & $75(12)$ \\
Asian & $12.5(2)$ \\
College generation status & \\
$\quad$ First generation & $37.5(6)$ \\
Continuing generation & $62.5(10)$ \\
Engaged in traditional undergraduate research during college \\
$\quad$ Yes & $93.8(15)$ \\
Published manuscript stemming from traditional undergraduate research \\
$\quad$ Yes & $25(4)$ \\
Average GPA \pm SD & $3.67 \pm 0.29$ \\
\hline
\end{tabular}

shared how their parents had PhDs and fully grasped the accomplishment of publishing, while others highlighted that their family or friends had very little understanding of what a publication is. Notably, all students who shared the publication described a joyful experience regardless of the extent to which others fully understood their accomplishment. Seven students (43.8\%) highlighted how becoming an author on a publication gave them a sense of personal pride. Four of the seven students who reported this were first-generation college students $(66.7 \%$ of the first-generation college students in the CURE). Specifically, these students highlighted that they were especially proud of this accomplishment, because they recognized that this was likely especially rare for someone who was the first in a family to attend college. Finally, seven students (43.8\%) highlighted that having a publication increased their sense of belonging to the scientific community. Some described that previously they had felt as if they were on the periphery of the scientific community, but formally contributing new knowledge to science made them more official members of the scientific community.

Professional Perceived Benefits of Authoring a CURE Publication. In addition to highlighting personal benefits stemming from the CURE publication, students highlighted five ways that they perceived they benefited professionally. All but one student in the CURE reported leveraging the publication for a professional gain. For example, students described adding it to their $\mathrm{CV}$ or talking about it in interviews with the intent to increase their competitiveness for additional research opportunities, scholarships, graduate school programs, and professional school programs. Additionally, 13 students (81.3\%) mentioned that they believed that the process of becoming an author equipped them with experience of publishing and the scientific review process. Three-fourths of the CURE students highlighted that the publication increased their confidence. Particularly, students described how it gave them confidence in their ability to do good research or to seek out research opportunities that they would have otherwise been too intimidated to pursue. In total, all but one student highlighted how the experience of publishing a paper provided them with clarity about the extent to which they wanted to pursue a scientific career; nine students (56.3\%) explained that the opportunity to publish strengthened their interest in a scientific research career, and six students (37.5\%) explained that the process of publishing a paper dampened their interest in a scientific research career. Even though some students learned that the process of conducting and publishing research was not what they were interested in, we consider this to be a benefit, because students were able to experience this process relatively early in their academic careers and had substantial time to explore additional career opportunities.

Perceived Benefits of Authoring a CURE Publication Related to Science and Research. Students reported that their perceptions of science and research changed in a positive way because of their participation in the process of publishing their CURE research. Six students (37.5\%) explained that the process of publishing increased their appreciation for science and research. Specifically, students explained that they gained a deeper understanding of what science entails, which in turn strengthened their appreciation for the process of science. Additionally, five students (31.3\%) highlighted that the publication helped them realize the importance of seeing the "bigger picture" in research. That is, students explained that the publication helped them understand how specific experiments fit into a larger study or aid in answering an overarching research question. Specifically, students often described how this experience helped them contextualize their contributions in future research projects that they went on to conduct in faculty member labs.

\section{Finding 2: Students' Perceptions of What One Needs to Contribute for Authorship Varied and Did Not Include Some of the Requirements Outlined by the ICMJE}

In the interview, students were asked what they thought one needs to contribute in order to be an author on a peer-reviewed scientific publication. Students' responses often described more than one requirement (Table 3). All 16 CURE students highlighted that it was necessary that an author write a part of the manuscript. Additionally, 14 students (87.5\%) mentioned that collecting data or performing experiments was necessary. Interestingly, students rarely mentioned the importance of intellectually engaging with the project as a requirement for publication. Specifically, six students (37.5\%) highlighted the need to have a deep conceptual understanding of the project, and two students $(12.5 \%)$ highlighted the need to conceive and design the study, interpret the data, "intellectually contribute" to the project, or provide a substantial idea that had the potential to influence a project. Notably, only two students mentioned that authors need to approve the manuscript, and no student mentioned the need to critically revise the manuscript for important intellectual content or the need to be accountable for the work.

When discussing authorship, the term "intellectual contribution" is often evoked in literature on authorship (Helgesson, 2015; Boffito et al., 2016; Patience et al., 2019) and likely in informal conversations by CURE instructors (Woolston, 2015). For example, when defending student authorship on the paper resulting from the Genomics 
TABLE 2. Ten student-perceived benefits of authoring a CURE publication

\begin{tabular}{|c|c|c|c|}
\hline Theme & Theme description & $\%(n)$ & Example student quote \\
\hline \multicolumn{4}{|c|}{ Personal benefits of authoring a CURE publication } \\
\hline $\begin{array}{r}\text { Built social } \\
\text { support }\end{array}$ & $\begin{array}{l}\text { Students described using the } \\
\text { CURE publication to } \\
\text { demonstrate productivity to } \\
\text { others, to gain social status } \\
\text { among peers, and to } \\
\text { celebrate with others in their } \\
\text { personal lives. }\end{array}$ & $100(16)$ & $\begin{array}{l}\text { "Right after we got the confirmation of } \\
\text { the publication I told my parents for } \\
\text { sure. I was like 'I'm not just messing } \\
\text { around in school, I'm doing } \\
\text { important things and I'm doing } \\
\text { really interesting things." } \\
\text { - Student } 12\end{array}$ \\
\hline $\begin{array}{l}\text { Developed } \\
\text { personal } \\
\text { pride }\end{array}$ & $\begin{array}{l}\text { Students viewed the publication } \\
\text { as a personal accomplishment } \\
\text { that they are proud of. }\end{array}$ & $43.8(7)$ & $\begin{array}{l}\text { "It was more like [the publication] is } \\
\text { something that I've accomplished } \\
\text { and I'm the first one in my family to } \\
\text { do something like that. I never really } \\
\text { thought that little me would be able } \\
\text { to do something like that." } \\
\text { - Student } 6\end{array}$ \\
\hline $\begin{array}{l}\text { Increased } \\
\text { belonging to } \\
\text { the scientific } \\
\text { community }\end{array}$ & $\begin{array}{l}\text { Students described that being an } \\
\text { author made them feel like } \\
\text { they are a part of the } \\
\text { scientific community. }\end{array}$ & $43.8(7)$ & $\begin{array}{l}\text { "I think it's like a personal competence } \\
\text { thing. Just being able to search a } \\
\text { construct in PubMed and see that } \\
\text { there's an actual publication that I } \\
\text { can reminisce about and know how } \\
\text { I contributed, I think that just helps } \\
\text { solidify my role in the scientific } \\
\text { community for sure."-Student } 8\end{array}$ \\
\hline
\end{tabular}

\section{Professional benefits of authoring a CURE publication}

$\begin{array}{cc}\begin{array}{c}\text { Built a } \\ \text { professional } \\ \text { profile }\end{array} & \begin{array}{c}\text { Students described putting the } \\ \text { publication on their CVs/ } \\ \text { résumés or mentioned that } \\ \text { they have used the publica- } \\ \text { tion to gain a scholarship, } \\ \text { research position, job, or to } \\ \text { get into graduate/profes- } \\ \text { sional school. }\end{array} \\ \begin{array}{c}\text { Increased } \\ \text { experience } \\ \text { in the } \\ \text { process of } \\ \text { publishing }\end{array} & \begin{array}{c}\text { gained experience in writing, } \\ \text { communicating science, or } \\ \text { became more familiar with } \\ \text { the peer-review process } \\ \text { through participating in the } \\ \text { process of publishing the } \\ \text { CURE manuscript. }\end{array} \\ \begin{array}{c}\text { Increased } \\ \text { confidence } \\ \text { in ability to } \\ \text { do research } \\ \text { or publish in }\end{array} & \begin{array}{l}\text { Students described that } \\ \text { publishing gave them } \\ \text { confidence in their ability to } \\ \text { engage in research or to } \\ \text { publish papers in the future. }\end{array}\end{array}$

the future
93.8 (15) "Putting [the publication] on my CV has helped me get sort of more recognition in some application to grad schools."-Student 9

81.3 (13) "I guess [publishing the CURE manuscript] gave me more of an idea of how the process of publishing a manuscript works as far as what all goes into it and the steps that are taken."-Student 11

75.0 (12) "I think knowing that I have contributed to [the CURE publication] has made me more willing to be like, 'I can do this. I can write [my undergraduate research thesis]." -Student 2
Provided career clarity: increased interest in research career
Students described that being an author clarified their career intentions, in that it moved them toward wanting a career in research.
56.3 (9) "Having the publication has made me realize I want to do some research, because I really do like it. So, I definitely want to get involved in medical research when I do become a physician."-Student 3
Example student quote

"[I shared the publication] definitely [with] my family and my boyfriend. I posted it on Facebook and was like, 'Look, it's a thing I did."'-Student 6

"Being able to say 'I'm published,' helped me tremendously, because I actually get to look at my name and see my own accomplishment." - Student 13

"Yeah, I could read all the scientific articles that I want, I could understand them all I want, but I wasn't really a part of that community. By doing the CURE publication [it] allowed me to be a part of the community I contributed to that science as a whole."-Student 12

"It was on my med school application and I got into med school, so I'll say [having a scientific publication] definitely helped [me get into medical school]."-Student 1

"[The publication was a benefit in terms of] learning exactly how the review process works. I think that was very, very insightful." Student 9

"My mindset before getting published in this class was that undergrads don't get published. Like, it's impossible. Journals aren't going to accept articles with undergrads' names on them. [The CURE publication] just completely collapsed that mindset. (...) With that collapse of that mindset, I was motivated to just publish, so I set my mind to that."-Student 14

"I think [the process of publishing the paper] just reinforced my desire to go into academia." -Student 14 
TABLE 2 Continued.

\begin{tabular}{|c|c|c|c|c|}
\hline Theme & Theme description & $\%(n)$ & Example student quote & Example student quote \\
\hline $\begin{array}{l}\text { Provided career } \\
\text { clarity: } \\
\text { Decreased } \\
\text { interest in } \\
\text { research } \\
\text { career }\end{array}$ & $\begin{array}{l}\text { Students described that being an } \\
\text { author clarified their career } \\
\text { intentions, in that it moved } \\
\text { them away from wanting a } \\
\text { career in research. }\end{array}$ & $37.5(6)$ & $\begin{array}{l}\text { "The publication showed me the side of } \\
\text { research and the side of science that } \\
\text { I didn't really want to be a part of. I } \\
\text { didn't want to be necessarily } \\
\text { completely research focused." } \\
\text { - Student } 12\end{array}$ & $\begin{array}{l}\text { "I think I learned that the world of } \\
\text { academic research and this paper } \\
\text { writing might not be what I want } \\
\text { to do with the rest of my life." - } \\
\text { Student } 16\end{array}$ \\
\hline \multicolumn{5}{|c|}{ Benefits of authoring a CURE publication related to perceptions of science and research } \\
\hline $\begin{array}{l}\text { Helped students } \\
\text { see the big } \\
\text { picture of } \\
\text { research }\end{array}$ & $\begin{array}{l}\text { Students described that the } \\
\text { publication allowed them to } \\
\text { see how the different parts of } \\
\text { research fit together to form } \\
\text { the project as a whole. }\end{array}$ & $31.3(5)$ & $\begin{array}{l}\text { "[Throughout the publication process], } \\
\text { I just started understanding more of } \\
\text { the research we did and how it } \\
\text { applied and that paper helped me } \\
\text { figure out that the bigger picture is } \\
\text { also important when we do those } \\
\text { experiments."-Student } 11\end{array}$ & $\begin{array}{l}\text { "I think [the publication helped me } \\
\text { see a bigger picture]. I think } \\
\text { without the level of understand- } \\
\text { ing that I had about what goes } \\
\text { into a publication, I wouldn't } \\
\text { have been able to connect the } \\
\text { dots [in research]. Without the } \\
\text { dots to connect, you can't really } \\
\text { see the full picture."-Student } 10\end{array}$ \\
\hline
\end{tabular}

Education Partnership CURE (Leung et al., 2015), the CURE developer highlighted that it was sufficient for students to intellectually contribute to the project in addition to reading, critiquing, and approving the manuscript (Woolston, 2015). As noted earlier, two students mentioned the need to "intellectually contribute to the project" as a requirement for

TABLE 3. Student-perceived necessary contributions for authorship of a peer-reviewed publication ${ }^{\mathrm{a}}$

\begin{tabular}{lc}
\hline $\begin{array}{l}\text { Student-perceived necessary contribution } \\
\text { for authorship }\end{array}$ & $\%(n)^{\mathrm{b}}$ \\
\hline Write part of the manuscript & $100(16)$ \\
Data collection/experimentation & $87.5(14)$ \\
Have a deep conceptual understanding of the project & $37.5(6)$ \\
Perform data analysis & $31.3(5)$ \\
Put time and effort into the project & $31.3(5)$ \\
Provide data that go into a figure in the manuscript & $25.0(4)$ \\
Read and provide minor edits on the manuscript & $18.8(3)$ \\
Conceive of and design the study & $12.5(2)$ \\
Interpret the data & $12.5(2)$ \\
"Intellectually contribute to the project" & $12.5(2)$ \\
Provide a substantial idea & $12.5(2)$ \\
Approve the manuscript & $12.5(2)$ \\
Critically revise the manuscript for important intellectual & $0.0(0)$ \\
$\quad$ content & \\
Be accountable for the research presented in the paper & $0.0(0)$
\end{tabular}

a Shaded themes coincide with ICMJE recommendations for authorship. All ICMJE recommendations are included in the table regardless of whether they were mentioned by students.

bStudents often provided multiple criteria that they perceived were necessary in order to be considered an author on a publication, which is why the percentages add to more than 100 . authorship. Given how ubiquitously this term is used in discussions pertaining to authorship, we wanted to reveal student perceptions about what others meant when they made references to "intellectually contributing" to a project. When we explicitly asked students what they thought the term meant in relation to a research project, students commonly mentioned four ways in which one might intellectually contribute to a project (Table 4). Specifically, 13 students $(81.3 \%)$ reported that intellectually contributing involved data collection or experimentation. Eleven students (68.8\%) perceived that it involved coming up with ideas about the research question or experimental design, and six students $(37.5 \%)$ mentioned that it entailed asking a question to challenge or further the research project. Finally, six students $(37.5 \%)$ reported that intellectually contributing involved writing part of the manuscript.

\section{Finding 3: Students Held Incomplete Ideas about Author- ship, Specifically about Authoring a CURE Publication} In addition to probing what students perceived was necessary for authorship in general, we asked students to what extent they felt they deserved to be listed as an author on the CURE manuscript. From this question, we identified incomplete conceptions that students held regarding authorship in general and authorship related to the CURE.

Students Perceived That Significantly Contributing to the Writing of the CURE Manuscript Was Integral for Deserving Authorship. In alignment with students' assumptions that writing a significant portion of the manuscript is required for authorship, $68.8 \%$ of students highlighted that they did not contribute to the writing of the paper, which they perceived meant they were less deserving of authorship. 
TABLE 4. Student perceptions of what "intellectually contributing" to a research project entails

\begin{tabular}{|c|c|}
\hline Theme & $\%(n)^{\mathrm{a}}$ \\
\hline Data collection/experimentation & $81.3(13)$ \\
\hline $\begin{array}{l}\text { Formulating ideas about the research question or } \\
\text { experimental design }\end{array}$ & $68.8(11)$ \\
\hline $\begin{array}{l}\text { Asking questions to challenge or further the } \\
\text { research project }\end{array}$ & $37.5(6)$ \\
\hline Write parts of the manuscript & $37.5(6)$ \\
\hline
\end{tabular}

Student 5: "I get hung up on including [my name as an author], because I didn't necessarily help write it. (...) My name is on it and I helped do the research, but I didn't help write it."

Student 12: "Yes, I did do a lot of the work in the lab setting to get [to the publication], but I didn't help out with the paper itself. So yes, I feel like I did earn it with doing the work and getting the results, like the pictures we took and seeing the results, but I didn't really do much on the paper."

Even the few students who explained that writing might not be required in order to be an author expressed how they grappled with what not writing the paper meant with regard to authorship. For example, both Student 2 and Student 3 highlighted how they recognized that one could still be an author even without contributing to the writing of the manuscript, but that this wasn't a conclusion they came to easily.

Student 2: "I did the experiments, I was there, I was active, but I did not assist in actively writing the paper. I felt very ashamed that I didn't help. (...) I didn't do enough to earn being on that paper, and me not assisting and writing it really just kind of cemented it. But now that I'm older I'm looking on it like, 'no, I feel like I deserved to be there."

Student 3: "I still have in my head, you're a coauthor, you're writing things. So that's why part of me feels like coauthors should contribute to the writing as well. But I don't think that's a necessity for [CURE] coauthors, because you can contribute a lot to the work without necessarily writing it. It's just stuck in my head."

Students Perceived That They Deserved Authorship Not Based on What They Directly Contributed to the Research, but Based on the amount of Work They Did in Comparison to the Amount of Work Done by Their Classmates in the CURE. In addition to considering their contribution to the writing of the manuscript, students supported their opinions about the extent to which they earned authorship by comparing what they accomplished to what others in their class accomplished. Forty-four percent of students compared the amount of work they did to the amount of work done by their classmates when explaining the extent to which they felt they deserved to be an author on the CURE manuscript.
In the CURE, students had the option of going in on the weekends to learn and assist with the microinjection of their designed, synthesized guide RNAs and Cas9 protein into the zebrafish embryos. Students often referenced this time as something that set them apart from the other students in the class and made them more deserving of authorship.

Student 8: "I remember going into the lab on weekends and putting in outside class work on the project. I think that relative to other classmates that puts me a little bit above average [with regard to deserving to be on the publication] in that sense."

Student 1: "Yeah, I definitely did contribute some data to it and I spent probably more time than a lot of the students in that class did. Not anything on them. I just had the time to do it. I probably spent a lot of time outside of that class working on these projects, so I feel I actually contributed a solid amount."

Other students felt that they did not do as much as others in the course and subsequently were unsure of whether they deserved to be considered an author.

Student 9: "I think that [other students] might have contributed more, which is why I'm not as sure that I did or did not deserve [to be an author]."

Student 13: "[Considering authorship], I'm always a person that I feel like I can do more. (...) I remember talking and watching especially, [another student in the CURE] and thinking, 'Oh, I really [want to do more like them.]”'

Students Expressed Concerns That Novice Students Were Not Deserving of Being Listed as an Author on a Manuscript. Students (43.8\%) also highlighted that they were only in their first year of college when they contributed to the CURE research that resulted in the paper. Students such as Student 1 and Student 4 highlighted their year in college as a way of explaining why they may have been unqualified to contribute to a particular activity, such as writing, that they considered important for authorship.

Student 1: "I wish I had been more involved [in the writing], but also as a freshman I didn't know what to do."

Student 4: "I think as a freshman you're missing [the] sort of knowledge of how to write scientifically. How to word things properly and make sure that you don't use any kind of language that's not scientific or anything like that. I think sort of, it's a lack of experience with scientific writing."

Additionally, $62.5 \%$ of students described that they perceived publication expectations to be different in a CURE compared with being in a traditional undergraduate research experience in a faculty member's lab. Specifically, students, like Student 10 , perceived that a CURE is meant for learning, whereas a faculty member's lab is focused on research. Students often questioned whether one can deserve to be on a publication if one is still learning. 
Student 10: "I contributed as much as I could have to the paper. However, I don't think that in a normal research lab, that was not a CURE, that it would have been enough. (...) The CURE environment is specifically to teach students how to be effective in research versus actually being in [a traditional undergraduate research experience] where the biggest goal is research and publications. Within a research lab setting, your job is to contribute to the research of the lab, your job is to contribute to the paper. And so, I think to be a coauthor on a paper your responsibility level needs to be higher versus if you were in a CURE environment where you're coming in as a freshman in college, you don't have any research in high school. So, I think it's going to be a different kind of requirement to achieve an authorship in a CURE setting."

Students had preconceived notions about how independently undergraduates work in traditional research experiences. Student 8 highlights how students in a CURE take direction from instructors and they assume that students in traditional research experiences make more decisions independently.

Student 8: "I think in a typical lab setting, at least what I experienced is that once you learn the ropes, you're eventually handed off a specific project and you work on that more independently. And so once it comes time to publication, it's you who's done most of the head work on that. And then I think there's a difference in the [CURE] because a lot of the ideas and everything, because we didn't really know a whole lot about the background at that point. So, we just learned along the way in that sense. We were taking direction, whereas I think working in a traditional lab environment, you're making the direction."

\section{DISCUSSION}

To date, there has been no research examining student perceptions of publications stemming from CUREs. In this study, we interviewed every student who enrolled in a CURE a year and a half after the students had authored a publication stemming from that CURE. We aimed to identify student-perceived benefits from the CURE publication and to further understand students' perceptions of what constitutes authorship.

Students in these interviews identified an array of perceived gains that stemmed from being authors on the CURE publication. We found that students in the CURE reported using their publication as a way to bolster their familial and peer support. Building such support is particularly important for undergraduates; studies have shown that having family and peer support is positively related to student adjustment, performance, and retention in college, especially for first-generation, Black, and Latinx students (Dennis et al., 2005; Nicpon et al., 2006; Yazedjian et al., 2007; Baker and Robnett, 2012). Students also cited the publication as a source of personal pride. Such pride likely boosts self-esteem, which protects against loneliness (McWhirter, 1997) and positively predicts student grades and retention in college (Munro, 1981; Napoli and Wortman, 1998; Nordstrom et al., 2014). Additionally, students reported that the CURE publication bolstered their sense of belonging in science, which highlights the magnitude of the impact that authoring publications may have on undergraduates, given the positive relationship between belonging in science and students' aca- demic motivation and achievement, well-being, and persistence in college (Hurtado and Carter, 1997; Anderman and Freeman, 2004; Trujillo and Tanner, 2014).

We found that the students perceived that the CURE publication helped them clarify and achieve their professional goals. Given that CUREs likely allow a more diverse group of students to author publications at the undergraduate level (Bangera and Brownell, 2014), that graduate and professional schools value publications (Cooper et al., 2019c), and that students indeed leverage CURE publications for professional gains, CUREs resulting in publications may be helping to create a more diverse and robust scientific workforce (Intemann, 2009). However, more research needs to be done to further understand how graduate and professional programs evaluate CURE publications compared with publications from traditional undergraduate research experiences.

In addition to identifying potential benefits of CURE publications, we found that the students in this CURE had varied perceptions of what is required in order to be considered an author on a peer-reviewed publication. Although there is not a universal set of authorship guidelines that the scientific community has agreed upon, the ICMJE provides the most widely used set of requirements in the sciences (Wager, 2007). When asked what someone needs to contribute in order to be an author on the manuscript, all students reported the need to write part of the manuscript. This was interesting, given that only two CURE students contributed to the first draft of the CURE manuscript. Notably, the ICMJE highlights involvement with the writing of the manuscript as one of the four requirements for authorship but distinguishes that, in order to qualify for authorship, an individual must draft the study manuscript or critically revise it for important intellectual content (ICMJE, 2019). This is a particularly important distinction for potential student-authors in a CURE, given that few single-term CUREs could provide students with the time needed to contribute to the conception and design of the study, acquire data, or interpret data (the first ICMJE requirement for authorship consideration), and contribute to the writing of the manuscript (the second ICMJE requirement). However, it is more reasonable to assume that students could contribute to the conception and design of the study, acquire data, or interpret data during the CURE, with the expectation that they would provide substantial edits to the manuscript after the CURE is complete. It would be possible to have a multi-term CURE to enable all students to participate in the writing process or to allow individual students to enroll in additional research credit focused on contributing to the preparation of the manuscript. It is unlikely that all students would be able to volunteer and contribute significantly to the writing of the manuscript outside the CURE. However, CURE instructors could structure their CUREs so that students have the opportunity to contribute to the writing of aspects of the manuscript, especially sections such as materials and methods, that may be partially written before analyses are complete. Asking every student in a CURE to contribute to the writing of a manuscript can be logistically difficult, but asking students to provide individual edits on the draft versions of the manuscript may be more feasible. Given the importance students placed on writing, allowing students to engage in some aspect of the writing of a CURE manuscript may enhance their science identities, but additional research is needed to explore this further. 
Additionally, only two students mentioned the third ICMJE requirement for authorship consideration, viz. approving the manuscript, and no students reported the need to critically revise the manuscript or take responsibility for the content of the article. Although all students in the CURE provided edits on the manuscript, approved the final version of the manuscript, and agreed to take responsibility for its contents, it became clear that they did not view these steps as integral to their status as authors. These data revealed that it is imperative that CURE instructors identify their own standard for authorship before the course and explicitly share these requirements with students. Otherwise, students may view steps such as approving the final manuscript as something that the CURE instructor expects of them, but unrelated to authorship. Not only will this help students better understand to what extent they are deserving of being an author, but it may also motivate students to accomplish authorship requirements, such as providing substantial edits to the manuscript.

Defining the term "authorship" is difficult for undergraduates (Mabrouk, 2016), and in this study we established that this is true even for students who are published authors. Because authorship is not routinely discussed in research groups (Abbott et al., 2020), CUREs provide a potentially powerful way to educate students about authorship, which is a concrete step toward meeting the explicit goal of CURE developers to integrate principles of ethics/RCR into CUREs (Olimpo et al., 2017; Diaz-Martinez et al., 2019). When discussing authorship with students, we urge CURE instructors to be mindful of the language they use when describing their standards for authorship. Specifically, we found that students had widely variable interpretations of what it means to intellectually contribute to a project. However, scientists may also have varying perceptions of what it means to intellectually contribute to a research project. For example, relatively recent publications that focus on the relationship between intellectual contribution and authorship discuss the idea of intellectual contribution differently. One study uses the term "intellectual contribution" but never explicitly defines it (Patience et al., 2019). The term is used throughout the paper to describe the activities that authors of papers report engaging in, such as developing research questions and supervising the research project. A second article defines "intellectual content," as "including writing, manipulating samples, writing programs, and analyzing data" (Boffito et al., 2016, p. 1133), and a third article highlights the ambiguity of the term "intellectual involvement" and does not provide a definition (Helgesson, 2015). Further, to our knowledge, no studies have examined scientists' perceptions of the concept of intellectual contribution. Given how ubiquitously this concept is referenced, and the ambiguity of its definition to both scientists and students, it is important to be as transparent as possible with students about what is meant by terms such as "intellectual contribution" or "intellectual involvement." This will help ensure that instructors do not unintentionally alienate students who may not be familiar with common research-related terms and that students do not interpret a term differently than the instructor who is using it.

This study also provided unique insight into incomplete conceptions that students may have about authorship and specifically authorship on CURE publications. We acknowledge that the assertion that students have incomplete conceptions of authorship could be considered a student deficit statement (Yosso, 2005). However, we perceive students' incomplete conceptions to be a result of inadequate instruction about authorship in the CURE; we hypothesize that such incomplete conceptions may have been remedied by more explicit instruction about authorship. For example, instead of focusing on what they directly contributed to the research project when considering their roles as authors, students tended to focus on the amount of work they contributed (e.g., how many hours, whether they went in on weekends) and compared it with their perception of the amount of work done by other students. This is especially disconcerting, because students who may not be able to put in work outside the class expectations, such as students who have part-time jobs or those with familial obligations, may be most likely to feel like they do not deserve authorship, which may deepen the perception that they do not belong in science. As such, this presents another reason for CURE instructors to highlight authorship standards early on in a CURE. Explaining that any student who meets those expectations will be listed as an author on potential subsequent publications may assuage concerns of students who may not be able to put work into the project beyond what is required. Additionally, students highlighted that they felt as though they did not know enough as first-year students to contribute to aspects such as writing a publication, and some expressed concern that they may not truly be contributing to the research while they are novices learning science. This is likely a conception harbored by many entering undergraduates. Instructors of CUREs directed at entry-level college students may benefit from explicitly highlighting the importance of legitimate peripheral participation (Lave and Wenger, 1991). Explaining that students, as new members of the scientific community, become more experienced by participating in simpler tasks that are still important to the overall work being done may help students understand that what they are doing is simultaneously helping them personally advance as scientists while also advancing the field of science. This could help students conceptualize how individuals at different points in their careers (e.g., first-year college students and full professors) can be authors on a publication.

\section{Limitations and Future Directions}

We chose to conduct an in-depth interview study because there is very little research on student perceptions of publications stemming from CUREs. The current results cannot be generalized beyond this specific CURE, conducted at a large R01 institution with high-performing honors students. However, our findings do provide a foundation for developing future surveys that can be given to students across different CUREs to examine the extent to which students' beliefs about publications reported here are shared by students publishing CURE data across different disciplines from other institutions. Notably, the students in the CURE were honors students; future studies could explore whether honors student sections of CUREs are more likely to lead to publication than non-honors student sections. However, we do not perceive that these students' honors status influenced whether their work in the CURE lead to a publication. From a scientific point of view, the novelty of targeting a gene and phenotype in a structure-function study using a new technology made this work publishable. 
Additionally, there are examples of CUREs with non-honors students that have led to publication (Pope et al., 2011a,b; Cooper et al., 2019a, 2020). We hope to build on this study with a quantitative study to examine the impact of publications on students, which will allow us to control for whether students are in an honors program. We acknowledge that our sample size is relatively small. However, in alignment with qualitative guidelines stating that saturation of the data is usually reached within six to 12 interviews (Guest et al., 2006), we reached saturation of our data within the first eight interviews with no new themes emerging thereafter. Additionally, doing an in-depth interview study of all students in a large CURE or from multiple CURES who have published is logistically challenging. Given the time that often lapses between finishing data analyses and writing of the manuscript and between submitting the manuscript for review and final acceptance for publication, it is unlikely that students who take a CURE during college can be easily reached for an interview and make time for an interview after their manuscript has been published. In our case, because students participated in the CURE during their first year at the university, we were able to reach all 16 students enrolled in the CURE and obtain their consent to participate in the study during their final year of college. Relatedly, because students engaged in the CURE during their first year of college, and published in their second year, they had a year and a half to experience the perceived benefits of the CURE publication. Students who engage in CUREs later in their college careers may not perceive that they experience as many benefits. When the CURE was offered, the CURE instructors were not sure whether the data collected and analyzed in the CURE would definitely result in a publication, or when it would be published, and did not foresee examining the impact of the publication on students. As such, we did not collect any data about what was explicitly said in the CURE about the publication. We relied on the memories of the CURE instructors about what was said; overall, the instructors recalled that there was very little discussion about authorship during the CURE. Yet, we are unable to assess how students developed their individual perceptions of what comprises authorship. We hope that future studies can more systematically assess how integrating RCR curriculum into CUREs affects students' perceptions of authorship and the benefits of CURE authorship; collecting data during the time when the publication is being prepared will allow conclusions to be drawn about how the CURE specifically affects students' perceptions of authorship. Finally, all but one student participated in a traditional undergraduate research experience in a faculty member's lab, and four students authored a peer-reviewed publication resulting from such an experience. We focused our interviews explicitly on students' experiences in the CURE and on the CURE publication and did not probe how students' traditional research experiences further impacted their perceptions of the CURE publication, because we hypothesized that the variability among research experiences would have made it difficult to draw conclusions. However, understanding how traditional research experiences affect student perceptions of authorship is an important area of further research. For example, future studies could compare the experiences of CURE students and non-CURE students who did and did not go on to participate in undergraduate research.

\section{CONCLUSION}

In this interview study of 16 student authors of a CURE publication, we examined 1) how students benefited from the CURE publication and 2) student perceptions of authorship. Students perceived that the CURE publication provided them with personal and professional benefits that are positively related to longer-term benefits such as academic performance and retention in college. Additionally, students held varied conceptions of what was required to be considered an author on a peer-reviewed publication. Although every student did view writing the manuscript as integral to being considered as an author, no student reported that critically revising the manuscript or taking responsibility for the contents of the article was necessary. Finally, we identified incomplete conceptions students held about CURE publications. Namely, that the extent to which they deserved to be authors on the CURE publication was dependent on how much work (e.g., time outside class) students put into the project compared with the work put in by their classmates, as opposed to what they actually contributed (e.g., collected data, analyzed data). Additionally, students had doubts that novice students were deserving of being listed as authors on CURE publications as they were still learning science. To help students maximize their gains from a CURE, instructors can explicitly highlight CURE research products, such as publications, as something that can benefit students. Additionally, we encourage CURE instructors to outline their own standards for publication, being intentional about using language that all students understand. Integrating this information into CUREs is a concrete way to begin to integrate principles of ethics/RCR into CUREs and to help all students understand what is expected of them.

\section{ACKNOWLEDGMENTS}

We thank the 16 students in the CURE who participated in this study, Diane Tucker, and the Science and Technology Honors (STH) Program at UAB. We also thank Rachel Scott, Sara Brownell, and Logan Gin for their feedback on earlier versions of this article.

\section{REFERENCES}

Abbott, L. E., Andes, A., Pattani, A. C., \& Mabrouk, P. A. (2020). Authorship not taught and not caught in undergraduate research experiences at a research university. Science and Engineering Ethics, 26(5), 2555-2599.

Anderman, L. H., \& Freeman, T. M. (2004). Students' sense of belonging in school. Advances in Motivation and Achievement, 13, 27-63.

Auchincloss, L. C., Laursen, S. L., Branchaw, J. L., Eagan, K., Graham, M., Hanauer, D. I., ... \& Rowland, S. (2014). Assessment of course-based undergraduate research experiences: A meeting report. CBE-Life Sciences Education, 13(1), 29-40.

Baker, C. N., \& Robnett, B. (2012). Race, social support and college student retention: A case study. Journal of College Student Development, 53(2), $325-335$.

Bangera, G., \& Brownell, S. E. (2014). Course-based undergraduate research experiences can make scientific research more inclusive. CBE-Life Sciences Education, 13(4), 602-606.

Bhatt, J. M., \& Challa, A. K. (2017). First year course-based undergraduate research experience (CURE) using the CRISPR/Cas9 genome engineering technology in zebrafish. Journal of Microbiology \& Biology Education, 19(1). https://doi.org/10.1128/jmbe.v19i1.1245

Birks, M., \& Mills, J. (2015). Grounded theory: A practical guide. Thousand Oaks, CA: Sage Publications.

Boffito, D. C., Patience, C. A., Patience, P. A., Bertrand, F., \& Patience, G. S. (2016). How do you write and present research well? 
8-Assign authorship according to intellectual involvement. Canadian Journal of Chemical Engineering, 94(6), 1127-1134.

Brownell, S. E., Hekmat-Scafe, D. S., Singla, V., Chandler Seawell, P., Conklin Imam, J. F., Eddy, S. L., ... \& Cyert, M. S. (2015). A high-enrollment course-based undergraduate research experience improves student conceptions of scientific thinking and ability to interpret data. CBE-Life Sciences Education, 14(2), ar21.

Brownell, S. E., \& Kloser, M. J. (2015). Toward a conceptual framework for measuring the effectiveness of course-based undergraduate research experiences in undergraduate biology. Studies in Higher Education, 40(3), 525-544.

Call, G. B., Olson, J. M., Chen, J., Villarasa, N., Ngo, K. T., Yabroff, A. M., ... \& Bui, C. (2007). Genomewide clonal analysis of lethal mutations in the Drosophila melanogaster eye: Comparison of the $\mathrm{X}$ chromosome and autosomes. Genetics, 177(2), 689-697.

Charmaz, K. (2006). Constructing grounded theory: A practical guide through qualitative research. Thousand Oaks, CA: Sage Publications.

Cooper, K. M., Blattman, J. N., Hendrix, T., \& Brownell, S. E. (2019a). The impact of broadly relevant novel discoveries on student project ownership in a traditional lab course turned CURE. CBE-Life Sciences Education. 18(4)

Cooper, K. M., Gin, L. E., Akeeh, B., Clark, C. E., Hunter, J. S., Roderick, T. B., . \& Brownell, S. E. (2019b). Factors that predict life sciences student persistence in undergraduate research experiences. PLOS ONE, 14(8). https:// doi.org/10.1371/journal.pone.0220186

Cooper, K. M., Gin, L. E., \& Brownell, S. E. (2019c). Diagnosing differences in what introductory biology students in a fully online and an in-person biology degree program know and do regarding medical school admission. Advances in Physiology Education, 43(2), 221-232.

Cooper, K. M., Hendrix, T., Stephens, M. D., Cala, J. M., Mahrer, K., Krieg, A. ... \& Eledge, B. (2018). To be funny or not to be funny: Gender differences in student perceptions of instructor humor in college science courses. PLOS ONE, 13(8), e0201258.

Cooper, K. M., Knope, M. L., Munstermann, M. J., \& Brownell, S. E. (2020) Students who analyze their own data in a course-based undergraduate research experience (CURE) show gains in scientific identity and emotional ownership of research. Journal of Microbiology \& Biology Education, 21(3), 2

Corwin, L. A., Graham, M. J., \& Dolan, E. L. (2015). Modeling course-based undergraduate research experiences: An agenda for future research and evaluation. CBE-Life Sciences Education, 14(1), es1.

Creswell, J. W. (1994). Research design: Qualitative and quantitative approaches. Thousand Oaks, CA: Sage.

Dennis, J. M., Phinney, J. S., \& Chuateco, L. I. (2005). The role of motivation, parental support, and peer support in the academic success of ethnic minority first-generation college students. Journal of College Student Development, 46(3), 223-236.

Diaz-Martinez, L. A., Fisher, G. R., Esparza, D., Bhatt, J. M., D'Arcy, C. E., Apodaca, J., ... \& Olimpo, J. T. (2019). Recommendations for Effective Integration of Ethics and Responsible Conduct of Research (E/RCR) Education into Course-Based Undergraduate Research Experiences: A Meeting Report. CBE-Life Sciences Education, 18(2), mr2.

Gin, L. E., Clark, C. E., Elliott, D. B., Roderick, T. B., Scott, R. A., Arellano, D., ... \& Brownell, S. E. (under review). An exploration across institution types of undergraduate life sciences student decisions to stay in or leave an academic-year research experience. CBE-Life Sciences Education.

Gin, L. E., Rowland, A. A., Steinwand, B., Bruno, J., \& Corwin, L. A. (2018). Students who fail to achieve predefined research goals may still experience many positive outcomes as a result of CURE participation. CBELife Sciences Education, 17(4), ar57.

Glesne, C., \& Peshkin, A. (1992). Becoming qualitative researchers: An introduction. London England: Longman.

Guest, G., Bunce, A., \& Johnson, L. (2006). How many interviews are enough? An experiment with data saturation and variability. Field Methods, 18(1). $59-82$.

Hall, B., Arshad, S., Seo, K., Bowman, C., Corley, M., Jhaveri, S. D., \& Ellington, A. D. (2010). In vitro selection of RNA aptamers to a protein target by filter immobilization. Current Protocols in Nucleic Acid Chemistry, $40(1), 9-3$
Helgesson, G. (2015). Scientific authorship and intellectual involvement in the research: Should they coincide? Medicine, Health Care and Philosophy, 18(2), 171-175.

Holliday, E. B., Jagsi, R., Wilson, L. D., Choi, M., Thomas, C. R., Jr., \& Fuller, C. D. (2014). Gender differences in publication productivity, academic position, career duration and funding among US academic radiation oncology faculty. Academic Medicine, 89(5), 767.

Hunter, A.-B., Laursen, S. L., \& Seymour, E. (2007). Becoming a scientist: The role of undergraduate research in students' cognitive, personal, and professional development. Science Education, 91(1), 36-74.

Hurtado, S., \& Carter, D. F. (1997). Effects of college transition and perceptions of the campus racial climate on Latino college students' sense of belonging. Sociology of Education, 70(4) 324-345.

Intemann, K. (2009). Why diversity matters: Understanding and applying the diversity component of the National Science Foundation's broader impacts criterion. Social Epistemology, 23(3-4), 249-266.

International Committee of Medical Journal Editors. (2019). Recommendations for the conduct, reporting, editing, and publication of scholarly work in medical journals. Retrieved May 1, 2021, from www.icmje .org/icmje-recommendations.pdf

Jordan, T. C., Burnett, S. H., Carson, S., Caruso, S. M., Clase, K., DeJong, R. J., .. \& Elgin, S. C. (2014). A broadly implementable research course in phage discovery and genomics for first-year undergraduate students MBio, 5(1), e01051-13

Kloser, M. J., Brownell, S. E., Shavelson, R. J., \& Fukami, T. (2013). Effects of a research-based ecology lab course: A study of nonvolunteer achievement, self-confidence, and perception of lab course purpose. Journal of College Science Teaching, 42(3), 72-81

Landis, J. R., \& Koch, G. G. (1977). An application of hierarchical kappa-type statistics in the assessment of majority agreement among multiple observers. Biometrics, 363-374.

Lave, J., \& Wenger, E. (1991). Situated learning: Legitimate peripheral participation. Cambridge, England: Cambridge University Press.

Lellis, A. D., Allen, M. L., Aertker, A. W., Tran, J. K., Hillis, D. M., Harbin, C. R., ... \& Browning, K. S. (2010). Deletion of the elFiso4G subunit of the Arabidopsis elFiso $4 \mathrm{~F}$ translation initiation complex impairs health and viability. Plant Molecular Biology, 74(3), 249-263.

Leung, W., Shaffer, C. D., Reed, L. K., Smith, S. T., Barshop, W., Dirkes, W., ... \& Xiong, D. (2015). Drosophila Muller F elements maintain a distinct set of genomic properties over 40 million years of evolution. G3: Genes, Genomes, Genetics, 5(5), 719-740

Linn, M. C., Palmer, E., Baranger, A., Gerard, E., \& Stone, E. (2015). Undergraduate research experiences: Impacts and opportunities. Science, 347(6222), 1261757.

Mabrouk, P. A. (2016). What knowledge of responsible conduct of research do undergraduates bring to their undergraduate research experiences? Journal of Chemical Education, 93(1), 46-55.

Mabrouk, P. A., \& Peters, K. (2000). Student perspectives on undergraduate research (UR) experiences in chemistry and biology. CUR Quarterly, 21(1), 25-33.

Malone, C. D., Falkowska, K. A., Li, A. Y., Galanti, S. E., Kanuru, R. C., LaMont, E. G., ... \& Piotrowski, N. K. (2008). Nucleus-specific importin alpha proteins and nucleoporins regulate protein import and nuclear division in the binucleate Tetrahymenathermophila. Eukaryotic Cell, 7(9), 1487-1499.

Maxwell, J. A. (2010). Using numbers in qualitative research. Qualitative Inquiry, 16(6), 475-482.

McWhirter, B. T. (1997). Loneliness, learned resourcefulness, and self-esteem in college students. Journal of Counseling \& Development, 75(6), 460469 .

Morales, D. X., Grineski, S. E., \& Collins, T. W. (2017). Increasing research productivity in undergraduate research experiences: Exploring predictors of collaborative faculty-student publications. CBE-Life Sciences Education, 16(3), ar42.

Munro, B. H. (1981). Dropouts from higher education: Path analysis of a national sample. American Educational Research Journal, 18(2), 133-141.

Nadile, E. M., Alfonso, E., Barreiros, B. M., Bevan-Thomas, W. D., Brownell, S. E., Chin, M. R., ... \& Gomez-Rosado, J. O. (2021). Call on me! Undergraduates' perceptions of voluntarily asking and answering questions in front of large-enrollment science classes. PLOS ONE, 16(1), e0243731. 
Napoli, A. R., \& Wortman, P. M. (1998). Psychosocial factors related to retention and early departure of two-year community college students. Research in Higher Education, 39(4), 419-455.

National Academies of Sciences, Engineering, and Medicine. (2017). Fostering integrity in research. Washington, DC: National Academies Press. Retrieved May 1, 2021, from http://doi.org/10.17226/21896

National Academies of Sciences \& Medicine. (2017). Undergraduate research experiences for STEM students: Successes, challenges, and opportunities. Washington, DC: National Academies Press.

National Institutes of Health. (2019). Update on the Requirement for instruction in the responsible conduct of research (p. 1). Retrieved May 1, 2021, from https://grants.nih.gov/grants/guide/notice-files/not-od-10-019.html

National Science Foundation. (2020). Proposal \& award policies \& procedures guide (PAPPG). Retrieved May 1, 2021, from www.nsf.gov/pubs/ policydocs/pappg20_1/nsf20_1.pdf

Nicpon, M. F., Huser, L., Blanks, E. H., Sollenberger, S., Befort, C., \& Kurpius, S E. R. (2006). The relationship of loneliness and social support with college freshmen's academic performance and persistence. Journal of College Student Retention: Research, Theory \& Practice, 8(3), 345-358.

Nordstrom, A. H., Goguen, L. M. S., \& Hiester, M. (2014). The effect of socia anxiety and self-esteem on college adjustment, academics, and retention. Journal of College Counseling, 17(1), 48-63.

Olimpo, J. T., Diaz-Martinez, L. A., Bhatt, J. M., \& D'Arcy, C. E. (2017). Integration of RCR and ethics education into course-based undergraduate research experiences in the biological sciences: A needed discussion. Journal of Microbiology \& Biology Education, 18(2).

Olson, J. M., Evans, C. J., Ngo, K. T., Kim, H. J., Nguyen, J. D., Gurley, K. G., ... \& Truong-N, K. T. (2019). Expression-based cell lineage analysis in Drosophila through a course-based research experience for early undergraduates. G3: Genes, Genomes, Genetics, 9(11), 3791-3800.

Patience, G. S., Galli, F., Patience, P. A., \& Boffito, D. C. (2019). Intellectual contributions meriting authorship: Survey results from the top cited authors across all science categories. PLOS ONE, 14(1), e0198117.

Pope, W. H., Ferreira, C. M., Jacobs-Sera, D., Benjamin, R. C., Davis, A. J., DeJong, R. J., ... \& Harris, A. D. (2011a). Cluster K mycobacteriophages: Insights into the evolutionary origins of mycobacteriophage TM4. PLOS ONE, 6(10), e26750.

Pope, W. H., Jacobs-Sera, D., Russell, D. A., Peebles, C. L., Al-Atrache, Z., Alcoser, T. A., ... \& Amy, N. E. (2011b). Expanding the diversity of mycobacteriophages: Insights into genome architecture and evolution. PLOS ONE, 6(1), e16329.

Pozun, Z. D., Tran, K., Shi, A., Smith, R. H., \& Henkelman, G. (2011). Why silver nanoparticles are effective for olefin/paraffin separations. Journal of Physical Chemistry C, 115(5), 1811-1818.

President's Council of Advisors on Science and Technology. (2012). Engage to excel: Producing one million additional college graduates with degrees in science, technology, engineering and mathematics. Washington, DC: U.S. Government Office of Science and Technology.

Rodenbusch, S. E., Hernandez, P. R., Simmons, S. L., \& Dolan, E. L. (2016). Early engagement in course-based research increases graduation rates and completion of science, engineering, and mathematics degrees. CBE-Life Sciences Education, 15(2), ar20.
Saldaña, J. (2015). The coding manual for qualitative researchers. Thousand Oaks, CA: Sage Publications.

Schmieder, E., Kmiotek-Meier, E., \& Saely, C. H. (2021). The destiny of an abstract: What predicts publication as a full text journal article? Zeitschrift für Evidenz, Fortbildung und Qualität im Gesundheitswesen, $160,62-67$.

Shaffer, C. D., Alvarez, C., Bailey, C., Barnard, D., Bhalla, S., Chandrasekaran, C., ... \& Du, C. (2010). The Genomics Education Partnership: Successful integration of research into laboratory classes at a diverse group of undergraduate institutions. CBE-Life Sciences Education, 9(1), 55-69.

Shortlidge, E. E., Bangera, G., \& Brownell, S. E. (2015). Faculty perspectives on developing and teaching course-based undergraduate research experiences. BioScience, 66(1), 54-62.

Shortlidge, E. E., Bangera, G., \& Brownell, S. E. (2017). Each to their own CURE: Faculty who teach course-based undergraduate research experiences report why you too should teach a CURE. Journal of Microbiology \& Biology Education, 18(2)

Thomas, D. R. (2003). A general inductive approach for qualitative data analysis. American Journal of Evaluation, 27(2).

Trenor, J. M., Miller, M. K., \& Gipson, K. G. (2011). Utilization of a think-aloud protocol to cognitively validate a survey instrument identifying social capital resources of engineering undergraduates. Vancouver, BC, Canada: American Society for Engineering Education.

Trujillo, G., \& Tanner, K. D. (2014). Considering the role of affect in learning: Monitoring students' self-efficacy, sense of belonging, and science identity. CBE-Life Sciences Education, 13(1), 6-15. https://doi.org/10.1187/ cbe.13-12-0241

Turner, A. N., Andersen, R. S., Bookout, I. E., Brashear, L. N., Davis, J. C., Gahan, D. M., ... \& Challa, A. K. (2018a). Analysis of novel domain-specific mutations in the zebrafish ndr2/cyclops gene generated using CRISPR-Cas9 RNPs. Journal of Genetics, 97(5), 1315-1325.

Turner, A. N., Andersen, R. S., Bookout, I. E., Brashear, L. N., Davis, J. C., Gahan, D. M., ... \& Challa, A. K. (2018b). Analysis of novel domain-specific mutations in the zebrafish-ndr2/cyclops-gene generated using CRISPR-Cas9 RNPs. BioRxiv, 277715. https://doi.org/10.1101/277715

Umali, A. P., LeBoeuf, S. E., Newberry, R. W., Kim, S., Tran, L., Rome, W. A., .. \& Kwan, M. (2011). Discrimination of flavonoids and red wine varietals by arrays of differential peptidic sensors. Chemical Science, 2(3), 439-445.

Wager, E. (2007). Do medical journals provide clear and consistent guidelines on authorship? Medscape General Medicine, 9(3), 16.

Wood, W. B. (2003). Inquiry-based undergraduate teaching in the life sciences at large research universities: A perspective on the Boyer Commission Report. Cell Biology Education, 2(2), 112-116

Woolston, C. (2015). Fruit-fly paper has 1,000 authors. Nature, 521(7552), $263-263$.

Yazedjian, A., Purswell, K., Sevin, T., \& Toews, M. (2007). Adjusting to the first year of college: Students' perceptions of the importance of parental, peer, and institutional support. Journal of the First-Year Experience $\&$ Students in Transition, 19(2), 29-46.

Yosso, T. J. (2005). Whose culture has capital? A critical race theory discussion of community cultural wealth. Race Ethnicity and Education, 8(1), 69-91. 